\title{
Evolution of anthropometric data and quality of life in active bariatric individuals
}

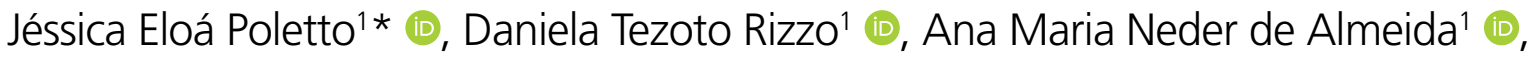

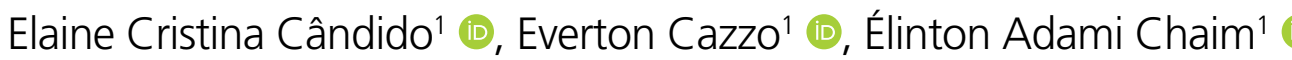

\begin{abstract}
SUMMARY
Obesity is a disease characterized by the accumulation of abnormal or excessive fat that can damage health. Bariatric surgery, an effective and safe way to treat this disease, requires multidisciplinary monitoring with an educational nature to change lifestyle. Adherence to routine physical activity can be a part of adopting a healthier lifestyle and can assist in the treatment of this disease and its related comorbidities. OBJECTIVE: Thus, the aim of this study was to analyze the correlation between the evolution of anthropometric variables and the domains of quality of life at different times, including at one year after bariatric surgery in very active and irregularly active individuals. METHODS: This was a longitudinal, observational, prospective, and analytical study. The collected data included anamnesis, level of physical activity (International Physical Activity Questionnaire Short Form), height, weight, body mass index (BMI), average waist circumference, percentage of fat, and the World Health Organization Quality of Life Assessment Bref.

RESULTS: Seven female individuals were evaluated and divided into two groups: a very active group and an irregularly active group. In the very active individuals, significant results were found in the evolutionary variables: weight $(p<0.001)$; body mass index $(p<0.001)$; average waist circumference $(p<0.001)$; percentage of fat $(p<0.001)$; and quality of life general $(p=0.001)$. In the irregularly active individuals, a significant result was found only in one evolutionary variable: body mass index $(p<0.001)$.

CONCLUSION: Thus, it is evident that the improvement and maintenance of good health is more effective in bariatric individuals who maintain a routine with regular physical activity.

KEYWORDS: Anthropometry. Motor activity. Quality of life. Bariatric surgery.
\end{abstract}

\section{INTRODUCTION}

Obesity is a disease characterized by the accumulation of abnormal or excessive fat that affects health ${ }^{1}$. Its etiology may involve several factors, such as genetic, endocrine, behavioral, social, economic, psychological, and environmental imbalances ${ }^{2}$.

In 2014 , there were 1.9 billion overweight or obese adults worldwide. Most of the global populations live in countries where the number of deaths from obesity exceeds the number of deaths caused by low weight ${ }^{3}$. According to the Brazilian Association for the Study of Obesity and Metabolic Syndrome ${ }^{4}$, about 82 million people were overweight or obese in Brazil in 2014.

The World Health Organization estimates that obesity will have involved 700 million adults and 75 million children by $2025^{3}$.

Along with obesity, the rates of cardiovascular diseases, diabetes, musculoskeletal disorders, infertility, and endometrial, breast, ovarian, prostate, liver, gallbladder, kidney, and colon neoplasms have also increased ${ }^{2,5}$.

Obesity and its related diseases are considered preventable and treatable 2 . Bariatric surgery is an effective and safe

\footnotetext{
'Universidade Estadual de Campinas, Hospital de Clínicas, Department Bariatric Surgery Outpatient Clinic - Campinas (SP), Brazil.

*Corresponding author: jeloap@hotmail.com

Conflicts of interest: the authors declare there are no conflicts of interest. Funding: none.

Received on June 29, 2021. Accepted on July 03, 2021.
} 
way to treat severe and refractory forms of this disease and requires multidisciplinary follow-up with a focus on educational lifestyle changes ${ }^{6}$.

In the long term, bariatric surgery can provide benefits such as significant and lasting body mass index (BMI) reduction ${ }^{7}$, decreased glucose, total cholesterol (LDL-c and VLDL-c), and triglyceride indices, increased HDL-c ${ }^{8}$, decreased prevalence of obstructive sleep apnea syndrome, dyslipidemia, and systemic arterial hypertension, increased adherence to physical activity, and improved quality-of-life (QoL) domains ${ }^{9-11}$.

Adherence to physical activities can be a part of a healthier lifestyle and help in the treatment of this disease and its related comorbidities ${ }^{12,13}$. Physical activity can be defined as any movement performed by the contraction of the musculoskeletal system increasing energy expenditure, when compared to rest ${ }^{14}$.

These activities can intensify energy expenditure, improve body composition, increase the ability to mobilize/oxidize fat, stimulate a thermogenic response, increase insulin sensitivity, decrease blood pressure, improve physical conditioning, improve psychosocial factors and self-esteem, and reduce anxiety ${ }^{12}$, in addition to improving the recovery of patients undergoing bariatric surgery and reducing mortality and existing chronic diseases ${ }^{2}$.

The relationship between bariatric patients and physical activity over a year after the surgical procedure is not clear in the specific literature. Thus, the objective of this study was to analyze the correlation between the progression of anthropometric variables and QoL domains at different times up to 1 year after bariatric surgery in very active and irregularly active patients treated at the bariatric surgery outpatient clinic, Hospital de Clínicas, State University of Campinas (UNICAMP).

\section{METHODS}

\section{Study design and ethical aspects}

This was a prospective and analytical, longitudinal, and observational study approved by the Research Ethics Committee of our institution, under opinion No. 2,038,341. All volunteers signed the Informed Consent Form (ICF).

\section{Data collection}

The data collection was performed at the bariatric surgery outpatient clinic, Hospital de Clínicas, UNICAMP, with grade II and III obese patients (at first participation) at four different times (i.e., first participation in the group, T0; after 10\% total weight loss, T1; immediate postsurgery, T2; and 1 year after surgery, T3) in a preoperative multidisciplinary bariatric surgery group, individually.

\section{Inclusion criteria}

- Grades II and III of obesity at T0;

- Age 18-59 years;

- Female sex;

- Consent to participate in all four evaluations.

\section{Exclusion criteria}

- Physical and/or intellectual disability and/or functional limitation;

- Vulnerable groups.

\section{Outcome measurements}

\section{Physical activity}

The physical activity level of participants was assessed using the International Physical Activity Questionnaire Short Form (IPAQ SF) $)^{15}$, which classifies the person as VERY ACTIVE, ACTIVE, IRREGULARLY ACTIVE A, IRREGULARLY ACTIVE B, and SEDENTARY. The classification was established by the score achieved, ranging from $0-4$, with $0=$ sedentary and $4=$ very active.

\section{Anthropometric measurements}

The measurements collected were height, weight, BMI, and mean waist circumference (WC).

\section{Fat percentage}

The "Prediction Equation for Obese Individuals - Women" was used ${ }^{16}$ at times 0,1 , and 2 to characterize the participants' fat percentage $(\% \mathrm{~F})$. This equation uses height (in $\mathrm{cm}$ ), weight (in $\mathrm{kg}$ ), and $\mathrm{WC}$ (in $\mathrm{cm}): \mathrm{WC}=[(\mathrm{W} 1+\mathrm{W} 2) / 2]$, where $\mathrm{W} 1$ is the waist circumference in centimeters measured at the midpoint between the sternum and the umbilicus (front) and the midpoint between the last rib and the iliac crest (lateral) and W2 is the waist circumference in centimeters measured at the level of the umbilical scar.

The "Prediction Equations for Normal Weight People" were used ${ }^{17}$ at time 3 to characterize the fat percentage $(\% \mathrm{~F})$ of participants, using WC (in cm), hip circumference (in $\mathrm{cm}$ ), height (in $\mathrm{cm}$ ), and age (in years) measurements.

\section{Quality of life}

The QoL was assessed by the World Health Organization Quality of Life Assessment Bref (WHOQOL BREF) questionnaire with two general questions and 24 facets divided into four domains (i.e., Physical, Psychological, Social Relations, and Environment $)^{18}$ and determined whether the QoL was very poor $=1$, poor $=2$, fair $=3$, $\operatorname{good}=4$, or very good $=5$. 


\section{Statistical analysis}

The data obtained were transcribed into the BioEstat software version 5.3, and a descriptive analysis of the variables was performed. The Shapiro-Wilk test was used to verify the normality of the data. The ANOVA test (one criterion) was used to analyze the progression of the same variables at different times. The significance level was $0.1 \%(\mathrm{p} \leq 0.001)$.

\section{RESULTS}

Seven women were evaluated, after being divided into two groups: a very active group and an irregularly active group. Four patients were classified as very active (because they achieved a score of 4 on the IPAQ), and three were classified as irregularly active (because they had a mean score between 1 and 2 on the IPAQ).

Table 1 presents a descriptive analysis of the data, with the mean and standard deviation of each variable.

Table 2 shows the $\mathrm{p}$ significance of all variables analyzed at the four times.

At T0, all patients weighed between $100 \mathrm{~kg}$ and $130 \mathrm{~kg}$, with a median of $110 \mathrm{~kg}$. The median was slightly above $100 \mathrm{~kg}$ at T1 and approximately $90 \mathrm{~kg}$ at T2. Notably, 1 year after the surgical procedure, the patients weighed between $60 \mathrm{~kg}$ and $70 \mathrm{~kg}$, with a median in the range of $65 \mathrm{~kg}$. Therefore, weight reduction between $\mathrm{T} 0$ and $\mathrm{T} 3$ was strongly significant, with $\mathrm{p}<0.001$.

As for BMI, at T0, the values were between $41 \mathrm{~kg} / \mathrm{m}^{2}$ and $46 \mathrm{~kg} / \mathrm{m}^{2}$, and the median was close to $44 \mathrm{~kg} / \mathrm{m}^{2}$. The median was $40 \mathrm{~kg} / \mathrm{m}^{2}$ at $\mathrm{T} 1$ and approximately $35 \mathrm{~kg} / \mathrm{m}^{2}$ at $\mathrm{T} 2$. Of note, 1 year after the surgical procedure, the patients had BMI values below $30 \mathrm{~kg} / \mathrm{m}^{2}$, with a median in the range of $25 \mathrm{~kg} /$ $\mathrm{m}^{2}$, which is considered normal. Therefore, BMI reduction between $\mathrm{T} 0$ and $\mathrm{T} 3$ was also strongly significant, with $\mathrm{p}<0.001$.

The WC measurements at $\mathrm{T} 0$ were between $120 \mathrm{~cm}$ and 130 $\mathrm{cm}$, as well as the median. At T1 and T2, the median was close to $110 \mathrm{~cm}$ and $100 \mathrm{~cm}$, respectively. At 1 year after bariatric surgery, the patients had a WC between $80 \mathrm{~cm}$ and $90 \mathrm{~cm}$, with a median in the range of $85 \mathrm{~cm}$. Therefore, this variable also showed a strongly significant reduction between $\mathrm{T} 0$ and $\mathrm{T} 3$, with $\mathrm{p}<0.001$.

The medians of $\% \mathrm{~F}$ were approximately $55,50,45$, and $35 \%$ at $\mathrm{T} 0, \mathrm{~T} 1, \mathrm{~T} 2$, and $\mathrm{T} 3$, respectively. These results also presented a $\mathrm{p}<0.001$, with a significantly decreased percentage of fat.

The general QoL (QoLG) score presented a highly significant result ( $\mathrm{p}=0.001$ ). At T0, QoLG was between 2 and approximately $>3$, with a median below 3; at T1, it was between almost 3 and approximately 3.5; at T2, it was between 4 and 5; and at T3, it was between 4.5 and 5 , with a median close to 4.7 and 4.8 .

Table 3 shows the p significance of all variables analyzed at the four times.

The only highly significant result in the irregularly active patients was the BMI $(\mathrm{p}<0.001)$. At T0, the BMI was between 45 $\mathrm{kg} / \mathrm{m}^{2}$ and $50 \mathrm{~kg} / \mathrm{m}^{2}$, with a median close to $50 \mathrm{~kg} / \mathrm{m}^{2}$. At T1, the BMI was between $40 \mathrm{~kg} / \mathrm{m}^{2}$ and $45 \mathrm{~kg} / \mathrm{m}^{2}$; at T2, it was between $38 \mathrm{~kg} / \mathrm{m}^{2}$ and $40 \mathrm{~kg} / \mathrm{m}^{2}$; and at T3, the BMI reduced to between $26 \mathrm{~kg} / \mathrm{m}^{2}$ and $30 \mathrm{~kg} / \mathrm{m}^{2}$, with a median close to $29 \mathrm{~kg} / \mathrm{m}^{2}$.

Table 1. Descriptive analysis of the sample of seven patients evaluated.

\begin{tabular}{l|c|c|c|c} 
& T0 & T1 & T2 & T3 \\
Weight $(\mathrm{kg})$ & $121.4( \pm 16.1)$ & $110.2( \pm 14.3)$ & $97.3( \pm 11.7)$ & $73.4( \pm 9.5)$ \\
\hline $\mathrm{BMI}\left(\mathrm{kg} / \mathrm{m}^{2}\right)$ & $45.4( \pm 2.7)$ & $41.3( \pm 2.3)$ & $36.4( \pm 2.1)$ & $21.5( \pm 2.5)$ \\
\hline WC $(\mathrm{cm})$ & $121.6( \pm 6.6)$ & $116.6( \pm 9.6)$ & $105.5( \pm 9.2)$ & $85.3( \pm 7.4)$ \\
\hline$\% F$ & $53.1( \pm 1.9)$ & $50.9( \pm 2)$ & $47.9( \pm 1.7)$ & $36.3( \pm 4.7)$ \\
\hline QoLG & $2.6( \pm 0.5)$ & $3.3( \pm 0.6)$ & $4.2( \pm 0.6)$ & $4.8( \pm 0.3)$ \\
\hline Physical QoL & $3( \pm 0.6)$ & $3.5( \pm 0.4)$ & $3.3( \pm 0.5)$ & $4.1( \pm 0.3)$ \\
\hline Psychological QoL & $3.2( \pm 0.5)$ & $3.7( \pm 0.6)$ & $3.8( \pm 0.3)$ & $4.1( \pm 0.3)$ \\
\hline Social relationships QoL & $3.6( \pm 0.8)$ & $4.1( \pm 0.8)$ & $4( \pm 0.4)$ & $4.3( \pm 0.7)$ \\
\hline Environment QoL & $3.3( \pm 0.6)$ & $3.7( \pm 0.4)$ & $3.7( \pm 0.5)$ & $3.7( \pm 0.5)$ \\
\hline
\end{tabular}

WC: waist circumference; \%F: percentage of fat; QoL: quality of life.

Table 2. The p-values depicting the significance of the progression analysis in very active individuals.

\begin{tabular}{c|c|c|c|c|c|c|c|c} 
Weight & BMI & WC & $\% \mathrm{~F}$ & QoLG & QoLPh & QoLPs & QoLSR & QoLE \\
\hline$<0.001$ & $<0.001$ & $<0.001$ & $<0.001$ & 0.001 & 0.028 & 0.068 & 0.283 & 0.857 \\
\hline
\end{tabular}

WC: mean waist circumference; \%F: percentage of fat; QoLG: general quality of life; QoLPh: quality of life physical domain; QoLPs: quality of life psychological domain; QoLSR: quality of life social relationships; QoLE: quality of life environmental. 
Table 3. The p-values depicting the significance of the progression analysis in irregularly active individuals.

\begin{tabular}{c|c|c|c|c|c|c|c|c} 
Weight & BMI & WC & $\% \mathrm{~F}$ & QoLG & QoLPh & QoLPs & QoLSR & QoLE \\
\hline 0.014 & $<0.001$ & 0.014 & 0.003 & 0.003 & 0.068 & 0.125 & 0.579 & 0.012 \\
\hline
\end{tabular}

WC: waist circumference; \%F: percentage of fat; QoLG: general quality of life; QoLPh: quality of life physical domain; QoLPs: quality of life psychological domain; QoLSR: quality of life social relationships; QoLE: quality of life environmental.

\section{DISCUSSION}

Bariatric surgery indicates a permanent change in the life of patients undergoing this procedure. Continuous professional follow-up and permanent changes to healthier lifestyle habits are needed ${ }^{19}$.

Failure to follow-up on treatment after surgery can lead to numerous problems $\mathrm{s}^{20-22}$. However, routine physical activity in association with postsurgical treatment may lead to more satisfactory long-term results than expected ${ }^{12,23,24}$.

The results found in this study corroborate this statement, as strongly significant reductions were found in all anthropometric measures and in the QoLG in the group of very active patients, ${ }^{70,11,13,23}$.

These results may also be related to a lower rate of postsurgical complications and weight relapse and to a good maintenance of the respiratory system ${ }^{20,21}$.

Physical activity can improve physical and psychosocial factors ${ }^{11}$ as well as muscle strength and functionality in patients undergoing the Roux-en-Y gastric bypass ${ }^{24}$, strengthening the results found in this study.

Severe malnutrition and infections can also be minimized with the combination of physical activity and a regular and balanced diet for bariatric patients, with indications and specialized professional monitoring ${ }^{22}$.

The patients classified as irregularly active showed a significantly reduced BMI.

Despite the significant BMI reduction in the irregularly active group, these values were lower than those found in the very active group.
The lack of more significant results is possibly due to the irregular physical activity and a minimally active routine, demonstrating that the irregular physical activity can be harmful after bariatric surgery ${ }^{13,20-23}$.

Despite the great improvement in the scores of the QoL domains assessed by the WHOQOL BREF at the four points of evaluation (Table 1), the statistical results did not show strong significance in any QoL domain (Tables 2 and 3). However, the patients report evident improvements in QoL domains 1 year after bariatric surgery ${ }^{9,20,21}$.

\section{CONCLUSION}

This study evidenced that the long-term treatment of obesity with surgical intervention combined with routine physical activity remarkably improved the anthropometric variables and QoL of the patients undergoing this treatment. It is worth emphasizing that further studies on this subject with a larger sample are needed.

\section{AUTHORS' CONTRIBUTIONS}

JEP: Conceptualization, Formal Analysis, Data Curation, Writing - original draft, Writing - review \& editing. DTR: Conceptualization, Data curation. Formal Analysis. AMNA: Data Curation. ECC: Data Curation. EC: Writing - review \& editing. ÉAC: Writing - review \& editing.

\section{REFERENCES}

1. Guyton AC, Hall JE. Tratado de Fisiologia Médica. 9th ed. Rio de Janeiro: Guanabara; 1997.

2. McArdle DW, Katch FI, Katch VL. Fisiologia do Exercício: Energia, Nutrição e Desempenho Humano. 5th ed. Rio de Janeiro: Guanabara Koogan S.A.; 2003.

3. Soares Júnior JM, Lobel A, Ejzenberg D, Serafıni PC, Baracat EC. Bariatric surgery in infertile women with morbid obesity: defınitive solution? Rev Assoc Med Bras (1992). 2018;64(7):565-7. https://doi.org/10.1590/18069282.64.07.565

4. World Health Organization. Fact Sheet Obesity and Overweight. Geneva: World Health Organization; 2016. [cited on Mar. 4, 2021]. Available from: http://www.who.int/mediacentre/ factsheets/fs311/en/
5. Associação Brasileira para o Estudo da Obesidade e da Síndrome Metabólica. Mapa da Obesidade. São Paulo: ABESO; 2015. [cited on mar. 4, 2021]. Available from: http://www.abeso. org.br/atitude-saudavel/mapa-obesidade

6. Yurcisin BM, Gaddor MM, DeMaria EJ. Obesity and bariatric surgery. Clin Chest Med. 2009;30(3):539-53,ix. https://doi. org/10.1016/j.ccm.2009.05.013

7. Kato KRA, Brim CA, Pizarro CB, Miranda AA, Yonamine F, Carvalho PM. Análise da variação de IMC de pacientes submetidos à cirurgia bariátrica. COORTE. 2018;8:9-15. http:// doi.org/10.52908/coorte.v0i08.107

8. Silva CF, Cohen L, Sarmento LA, Rosa FMM, Rosado EL, Carneiro JRI, et al. Efeitos no longo prazo da gastroplastia redutora em y-de-roux sobre o peso corporal e comorbidades clínico 
metabólicas em serviço de cirurgia bariátrica de um hospital universitário. Arq Bras Cir Dig. 2016;29(Suppl 1):20-3. https:// doi.org/10.1590/0102-6720201600S10006

9. Santos MMM, Orth LC, Prá M, Uberti MF, Trevisol FS. Avaliação da condição de saúde e da qualidade de vida no pós-operatório tardio de pacientes submetidos à cirurgia bariátrica. RBONE. 2018 [cited on Mar. 4, 2021];12(74):730-7. Available from: https://repositorio.animaeducacao.com.br/bitstream/ ANIMA/2682/1/Artigo\%20bari\%c3\%a1 trica\%20GPEC.pdf

10. Poletto JE, Rizzo DT, Baltieri L, Cazzo E, Chaim EA. Influência da obesidade e das medidas antropométricas sobre a incontinência urinária e a qualidade de vida: um estudo piloto. RBONE. 2018[cited on Mar. 4, 2021];12(75):901-7. Available from: https://dialnet.unirioja.es/servlet/ articulo? codigo $=6987334$

11. Poletto JE, Rizzo DT, Neder AM, Cândido EC, Cazzo E, Chaim EA. Impacto da obesidade e dos parâmetros antropométricos sobre a qualidade de vida e a qualidade do sono. RBONE. 2019[cited on Mar. 4, 2021];13(81):831-7. Available from: link.gale.com/apps/doc/A627969307/ AONE? u=anon 61e42d8d\&sid=googleScholar\&xid=040ae4de

12. Matsudo VKR. Vida ativa para o novo milênio. Revista Oxidologia. 1999[cited on Mar. 4, 2021];18-24. Available from: http:// allchemy.iq.usp.br/estruturando/revistas/rdo-VIII-5.html

13. Poletto JE, Rizzo DT, Cândido EC, Neder AM, Chaim FDM, Chaim EA. The influence of physical activity on quality of life in morbidly obese patients with urinary dysfunction. J. Public Health Med. 2020;8(3):72-6. https://doi.org/10.11648/j. sjph.20200803.12

14. Lazzoli JK; Nóbrega ACL; Carvalho T; Oliveira MAB; Teixeira JAC; Leitão MB; et al. Atividade física e saúde na infância e adolescência. Rev Bras Med Esporte. 1998;4(4):107-9. https:// doi.org/10.1590/S1517-86921998000400002

15. Pardini R, Matsudo S, Araújo T, Matsudo V, Andrade E, Braggion G, et al. Validação do questionário internacional de nível de atividade física (IPAQ - versão 6): estudo piloto em adultos jovens brasileiros. Rev Bras Cien Mov. 2001;9(3):45-51. http:// doi.org/10.18511/rbcm.v9i3.393
16. Weltman A, Levine S, Seip RL, Tran ZV. Accurate assessment of body composition in obese females. Am J Clin Nutr. 1988;48(5):1179-83. http://doi.org/10.1093/ajcn/48.5.1179

17. Tran ZV, Weltman A. Generalized equation for predicting body density of women from girth measurements. Med Sci Sports Exerc. 1989;21(1):101-4. http://doi.org/10.1249/00005768198902000-00018

18. The World Health Organization Quality of Life assessment (WHOQOL): position paper from the World Health Organization. Soc Sci Med. 1995;41(10):1403-9. http://doi.org/10.1016/02779536(95)00112-k

19. Chaim EA, Pareja JC, Gestic MA, Utrini MP, Cazzo E. Preoperative multidisciplinary program for bariatric surgery: a proposal for the Brazilian Public Health System. Arq Gastroenterol. 2017;54(1):70-4. http://doi.org/10.1590/ S0004-2803.2017v54n1-14

20. Raspante LBP, Barquette ÁDC, Motta EGPC, Ribeiro MA, Ramos LFM, Moreira W. Review and pictorial essay on complications of bariatric surgery. Rev Assoc Med Bras (1992). 2020;66(9):128995. http://doi.org/10.1590/1806-9282.66.9.1289

21. Pazzianotto-Forti EM, Baltieri L, Brigatto P, Costa CMD, Rocha MRSD, Rasera-Júnior I. Bilevel positive airway pressure in two moments after bariatric surgery. Rev Assoc Med Bras (1992). 2019;65(9):1161-7. http://doi.org/10.1590/18069282.65.9.1161

22. Furlan AAC, Junqueira-Franco MVM, Oliveira JCS, Favaris JWS, Marchini JS, Cunha SFC. Severe malnutrition after bariatric surgery and clinic manifestations of infection. Rev Assoc Med Bras (1992). 2019;65(9):1151-5. http://doi.org/10.1590/18069282.65.9.1151

23. Soares TD. Efeitos do exercício físico na depressão: um ensaio clínico com mulheres obesas sedentárias [Dissertação]. Santa Maria: Universidade Franciscana, 2019.

24. Alves SP, Anjos RS, Feliciano FT, Lamarca F, Dutra ES, Carvalho $\mathrm{KMB}$, et al. Associação entre força muscular isocinética e funcionalidade em pacientes submetidos à cirurgia bariátrica. Rev Bras Pesqui Saude. 2018;5(9):21-6. http://doi.org/10.6084/ m9.figshare. 8111249 